\title{
Transgenic tomato line expressing modified Bacillus thuringiensis cry $1 A b$ gene showing complete resistance to two lepidopteran pests
}

\author{
Bhupendra Koul', Sugandha Srivastava ${ }^{2}$, Indraneel Sanyal ${ }^{1}$, Bhuminath Tripathi ${ }^{3}$, Vinay Sharma ${ }^{4}$ \\ and Devindra Vijay Amla*
}

\begin{abstract}
The modified truncated Bt-CrylAb gene of Bacillus thuringiensis has been used for the development and selection of over expressing transgenic events in a commercially important variety of tomato (Solanum lycopersicum L.) by Agrobacterium-mediated leaf-disc transformation procedure. The integration and inheritance of crylAb gene in $\mathrm{T}_{0}$ transgenic plants and their progenies were determined by PCR, RT-PCR and Southern blot hybridization analysis. The toxin expression was monitored by double antibody sandwich enzyme-linked immunosorbent assay (DAS-ELISA). The transgenic line Ab25 E, expressing $0.47 \pm 0.01 \%$ Cry $1 \mathrm{Ab}$ toxin of total soluble protein (TSP) was finally selected in the $\mathrm{T}_{4}$ generation from the segregating population, showing $100 \%$ mortality to the second instar larvae of $\mathrm{H}$. armigera and S. litura and minimal damages to leaves and fruits. Southern blot analysis data revealed single copy introgression of cry $1 \mathrm{Ab}$ gene in highly-expressing Ab25 E transgenic line and expression of Cry $1 \mathrm{Ab}$ toxin of molecular mass $\sim 65 \mathrm{kDa}$ was evident in Western blot analyses in transgenic plants of $T_{4}, T_{5}$ and $T_{6}$ generation. Receptor binding assay performed with partially purified Cry1Ab protein from Ab25 E transgenic tomato line, confirmed efficient protein-protein interaction of Cry1Ab toxin with receptor(s) of both the insects. The higher level of Cry $1 \mathrm{Ab}$ toxin $(\approx 0.47 \pm 0.01 \% \mathrm{TSP})$ did not affect the normal in vitro regeneration, plant development and fruit yield in this transgenic line. This high expressing Cry1Ab homozygous transgenic line can be a useful candidate in tomato breeding programmes for introgression of important agronomical traits.
\end{abstract}

Keywords: Agrobacterium tumefaciens; Bt-cry1Ab; Genetic transformation; Insect mortality; Tomato; Vegetative leaves

\section{Background}

Tomato (Solanum lycopersicum L.) is a major vegetable crop plant and extensively consumed either raw or cooked. Besides being a dietary source of antioxidants, vitamins, minerals and fiber it is also a model system for studies on fruit development and functional genomics (Klee and Giovannoni 2011). A wide range of microbial pathogens and insect pests are known to attack tomato, particularly polyphagous lepidopteran insect Helicoverpa armigera, the common fruit borer which primarily damages the fruit, while Spodoptera litura damages the leaves causing severe losses to the crop productivity.

\footnotetext{
* Correspondence: dvamla@rediffmail.com

'Plant Transgenic Lab, CSIR-National Botanical Research Institute, P.O. Box 436, Rana Pratap Marg, Lucknow 226001 , India

Full list of author information is available at the end of the article
}

There is a possibility of developing stable insect-resistant tomato lines through the expression of insecticidal gene of Bacillus thuringiensis (Bt), as documented successfully in several crop plants like cotton, maize, soybean, rice, canola and potato (Sanahuja et al. 2011; Tabashnik et al. 2011). The application of Bt-toxins for insect pest resistance has emerged as a powerful tool, being chemically free, eco-friendly and highly specific against target insects due to the presence of specific receptors in the midgut, while being non-toxic to beneficial insects and vertebrates owing to the lack of the receptors for toxin interaction and binding (Pigott and Ellar 2007; Bravo et al. 2011). Incorporation of $c r y 1 A b$ insecticidal crystal protein gene in large number of crop plants particularly rice, tomato, maize, sugarcane and cotton have shown considerable protection against different lepidopteran insects and significant enhancement in productivity (Ye et al.

\section{勿}

(C) 2014 Koul et al.; licensee Springer. This is an Open Access article distributed under the terms of the Creative Commons Attribution License (http://creativecommons.org/licenses/by/2.0), which permits unrestricted use, distribution, and reproduction in any medium, provided the original work is properly cited. 
2001; Kumar and Kumar 2004; Dutton et al. 2005; Arvinth et al. 2010; Khan et al. 2013).

The Cry1Ac toxin of $B$. thuringiensis has broader specificity than those of Cry1Aa and Cry1 Ab and is primarily a class 1 and 3 aminopeptidase N (APN) binding protein whereas Cry1Aa and Cry1Ab are class $1 \mathrm{APN}$ binding proteins (Pigott and Ellar 2007). Although Cry1Ac has been documented to be most effective toxin against $H$. armigera owing to its binding to different receptors in target insect but is ineffective against $S$. litura (Bravo et al. 2004; Purcell et al. 2004). It is also reported that the rate of pore formation by Cry1Ac is lower than that of Cry1Ab (Kato et al. 2006). The Cry1Ab toxin has been reported to interact by diverse modes in monomeric and oligomeric forms with brush border membrane vesicles of different lepidopteran insects for pore-formation (Zhang et al. 2005, 2006; Kato et al. 2006; Padilla et al. 2006; Vachon et al. 2012; Pardo Lopez et al. 2013). Moreover, over-expression of Cry1Ac toxin in plants is a major constrain for being toxic to in vitro regeneration and development of transformed plant cells. Selection of transgenic events expressing high-levels of Cry1Ac toxin is still not a routine procedure (Diehn et al. 1996; De Rocher et al. 1998; Mehrotra et al. 2011; Rawat et al. 2011). Interestingly, cry $1 A b$ gene shares significant homology with cry1Ac (Schnepf et al. 1998) which is also effective against large number of lepidopteran insects and is at the same time non-toxic during in vitro development of transgenic plants expressing high-levels of the toxin (Estela et al. 2004; Padilla et al. 2006; Pacheco et al. 2009). To overcome these problems, several modifications have been incorporated in the native $c r y 1 A c$ and cry $1 \mathrm{Ab}$ genes for stability of the transcripts including, elimination of polyadenylation sites, inclusion of plantpreferred codons and enhanced GC ratio (Perlak et al. 1990; De Rocher et al. 1998).

Considering these facts we have adopted the strategy of over-expressing the modified truncated version of $c r y 1 A b$ gene for the selection of transgenic events over expressing Bt Cry1 $\mathrm{Ab}$ toxin in a commercial tomato variety Pusa early dwarf (PED), which is grown round the year throughout North India. In this paper we have reported the selection of high expressing stable transgenic lines of tomato in $\mathrm{T}_{4}$ generation after extensive screening and selection of progenies starting with the promising $\mathrm{T}_{0}$ transgenic plants. Insect bioassay performed under laboratory conditions with detached leaves and fruits of transgenic line Ab25 E over expressing CrylAb toxin showed complete mortality of two polyphagous insect pests $H$. armigera and $S$. litura. The $\mathrm{T}_{6}$ generation of this transgenic tomato line, did not show any negative effect on plant growth, development and fruit yield compared to non transgenic control plants.

\section{Results}

Agrobacterium-mediated transformation and regeneration of transgenic tomato plants

The excised and preconditioned vegetative leaf explants of commercial variety of tomato (PED) complementary to Agrobacterium-mediated transformation were used, for high frequency recovery of $\mathrm{T}_{0}$ transgenic plants along with effective management of escapes and development of chimeric transgenic plants. Leaf disc explants that were kept on MS basal medium for in vitro regeneration served as positive control, while those on kanamycin-supplemented medium served as the negative control. Every responding leaf disc on an average produced about 5.80 number of elongated shoots per explant in $96 \pm 2 \%$ responding explants on MS basal medium supplemented with optimal concentration of carbon source (3\% maltose) and $2.5 \mathrm{mgl}^{-1}$ BAP (Table 1). Two consecutive selection cycles on kanamycin-supplemented medium resulted into a maximum transformation frequency of $28.20 \%$, thus reflecting the efficacy of the optimized tomato transformation and regeneration procedure. The comprehensive data on tomato transformation with binary vector pBIN200 harbouring modified and truncated $1845 \mathrm{bp}$ cry $1 \mathrm{Ab}$ gene (Figure $1 \mathrm{~A}$ ) and selection of $\mathrm{T}_{0}$ primary transformants from a series of experiments is summarized in Table 2. A total of $143 \mathrm{~T}_{0}$ transgenic tomato plants were developed and categorized into three groups on the basis of quantitative expression of Cry1 Ab toxin. The first group comprising of 86 plants were expressing Cry1Ab toxin maximally up to $0.002 \%$ of TSP; second group of 32 plants expressing up to $0.02 \%$ of TSP, while the third group comprising of 25 plants expressing $\mathrm{Cry} 1 \mathrm{Ab}$ toxin ranging from $0.02-0.13 \%$ of TSP and were

\begin{tabular}{|c|c|c|c|}
\hline $\begin{array}{l}\text { Carbon } \\
\text { source (\%) }\end{array}$ & $\begin{array}{c}\text { PGR }{ }^{1} \\
\left(\mathrm{mg} \mathrm{l}^{-1}\right)\end{array}$ & $\begin{array}{l}\text { Responding } \\
\text { explants }^{2}(\%)\end{array}$ & $\begin{array}{l}\text { Elongated shoots per } \\
\text { responding explant }\end{array}$ \\
\hline $2 \%$ Sucrose & 1.0 BAP & $55.26^{\mathrm{a}}$ & $2.70^{\mathrm{ab}}$ \\
\hline $2 \%$ Sucrose & $2.5 \mathrm{BAP}$ & $57.00^{a}$ & $2.93^{b}$ \\
\hline $2 \%$ Sucrose & $1.0 \mathrm{ZET}$ & $56.10^{\mathrm{a}}$ & $2.98^{b}$ \\
\hline $2 \%$ Sucrose & $2.5 \mathrm{ZET}$ & $49.26^{a}$ & $1.95^{\mathrm{ab}}$ \\
\hline 3\% Maltose & 1.0 BAP & $83.73^{b}$ & $1.57^{\mathrm{a}}$ \\
\hline 3\% Maltose & $2.5 \mathrm{BAP}$ & $96.20^{b}$ & $5.80^{c}$ \\
\hline 3\% Sucrose & $2.5 \mathrm{BAP}$ & $87.28^{b}$ & $4.75^{c}$ \\
\hline 3\% Maltose & 1.0 ZET & $60.00^{\mathrm{a}}$ & $2.20^{\mathrm{ab}}$ \\
\hline 3\% Maltose & $2.5 \mathrm{ZET}$ & $92.30^{b}$ & $2.70^{\mathrm{ab}}$ \\
\hline
\end{tabular}

Duncan's Multiple Range Test (DMRT) was performed to compare means and data having different letter within a column are significantly different $(P<0.05)$.

${ }^{1}$ Plant growth regulator.

${ }^{2}$ Percentage of regenerating explants on media supplement under trial. BAP: 6-Benzyladenine, ZET: Zeatin. 
A
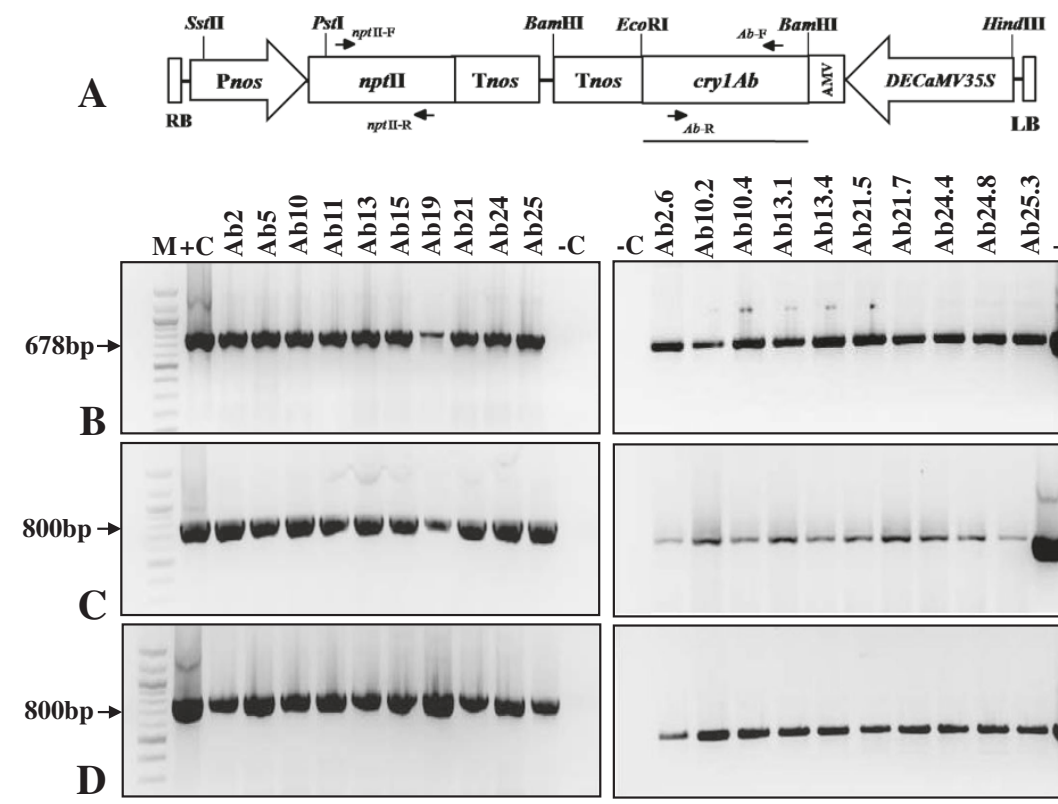

峁

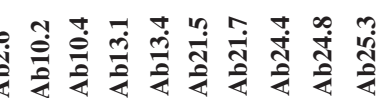
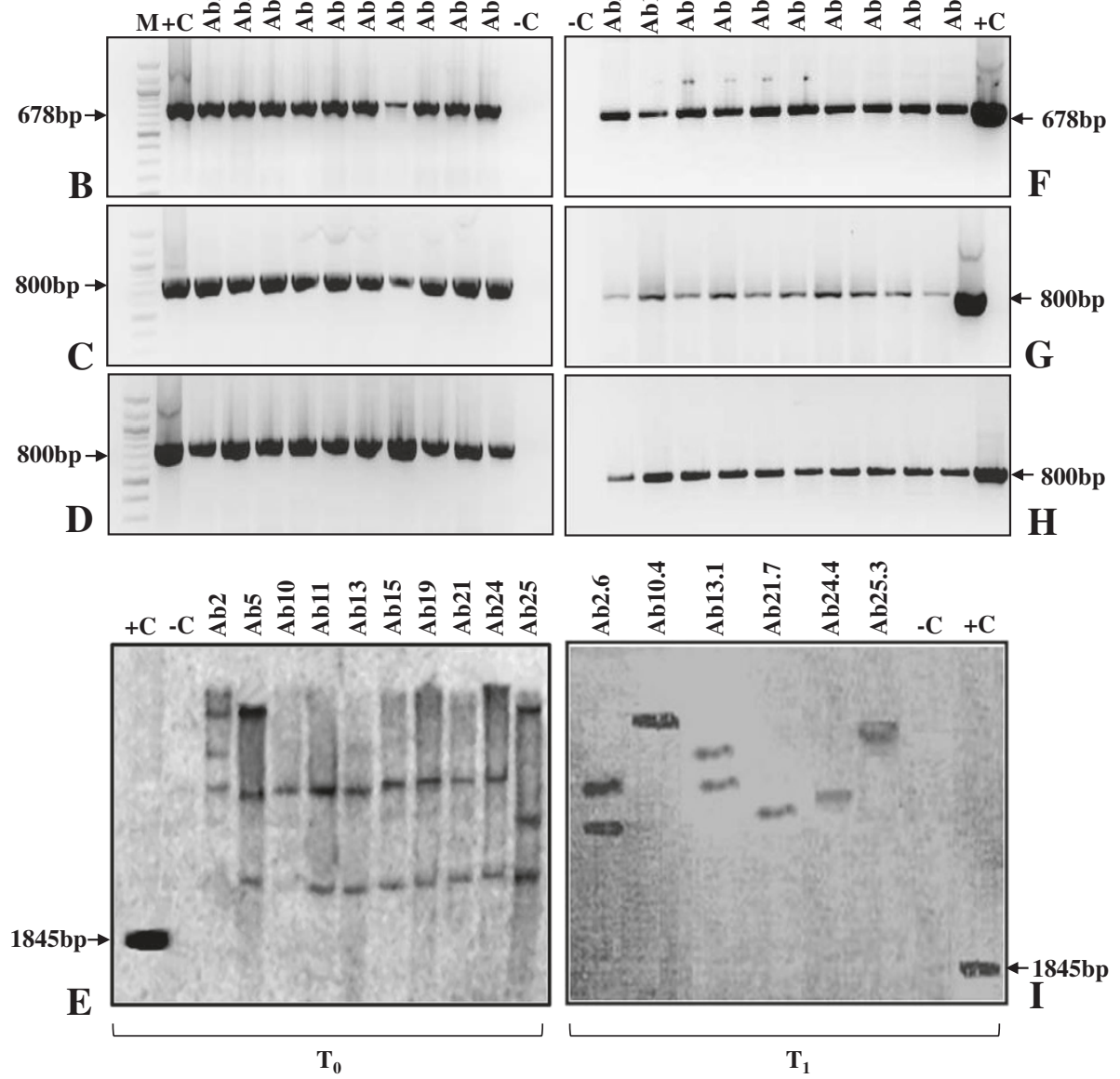

Figure 1 Schematic diagram of the T-DNA region of binary vector pBIN200 and molecular characterization of $T_{0}$ and $T_{1}$ transgenic tomato plants. A T-DNA region of pBIN200 harbouring cry 7 Ab gene driven by constitutive DECaMV35S promoter. Different PCR primers used in the present study are shown with arrow marks at their respective binding positions: $n p t l l-F, n p t l l-R$ for $n p t l l$ gene and $A b-F, A b-R$ for $c r y 7 A b$ gene amplification, respectively. Bold line represents $1845 \mathrm{bp} \mathrm{BamHI}$ and EcoRl fragment of cry 1 Ab gene used for preparation of radiolabelled probe for Southern blot hybridization analysis in the present study. RB and LB: right and left border sequences, nptll: neomycin phosphotransferase gene, AMV: alfalfa mosaic virus 5' UTR sequence, cry 7 Ab: modified truncated 1845 bp cry 7 Ab gene of B. thuringiensis, DECaMV35S: CaMV35S promoter with duplicated enhancer, Pnos: nos promoter, Tnos: nos terminator. PCR amplification of genomic DNA from transgenic tomato in $T_{0}$ and $T_{1}$ generations. B, F 678 bp amplification of nptll gene. C, G 800 bp amplification of cry 7 Ab gene. D, H RT-PCR analysis of $T_{0}$ and $T_{1}$ transgenic tomato showing $800 \mathrm{bp}$ amplicon of cry $7 \mathrm{Ab}$ gene transcripts, respectively, $+\mathrm{C}$ : truncated $1845 \mathrm{bp}$ cry $7 \mathrm{Ab}$ gene as positive control. -C: DNA from non-transformed plant as negative control. E, I Southern blot analysis of PCR positive $T_{0}$ transgenic plants and randomly selected $T_{1}$ transgenic plants. +C: 1845 bp fragment of truncated crylAb gene. -C: DNA from non-transformed control plant.

considered as the promising group of $\mathrm{T}_{0}$ transgenic plants for further investigation to select the high expressing transgenic lines (Additional file 1: Table S1).

\section{Molecular characterization of the transgenic plants}

Ten $\mathrm{T}_{0}$ transgenic tomato plants from the third group expressing higher level of Cry1 Ab toxin, were selected and verified for the incorporation of $n p t \mathrm{II}$ and $c r y 1 A b$ genes by PCR amplification and RT-PCR for cry $1 A b$ transcript. Results of PCR and RT-PCR assays performed with these transgenic plants have shown the amplification of expected amplicons of $678 \mathrm{bp}$ and $800 \mathrm{bp}$ for $n p t I I$ and $c r y 1 A b$ genes respectively (Figure 1B-D). Southern blot hybridization of these ten $\mathrm{T}_{0}$ over expressing transgenic plants with $1845 \mathrm{bp} c r y 1 \mathrm{Ab}$ gene probe revealed the independent nature of transgenic events. Most of the $\mathrm{T}_{0}$ transgenic plants showed double copy insertion while few plants showed single copy insertion of the 
Table 2 Tomato transformation, selection on kanamycin supplemented medium and regeneration of transgenic plants

\begin{tabular}{|c|c|c|c|c|c|c|c|c|c|}
\hline \multirow[b]{2}{*}{ Experiment } & \multicolumn{4}{|c|}{ I $^{\text {st }}$ selection } & \multicolumn{5}{|c|}{ II $^{\text {nd }}$ selection } \\
\hline & $\begin{array}{l}\text { No. of } \\
\text { explants } \\
\text { used (A) }\end{array}$ & $\begin{array}{l}\text { No. of } \\
\text { responding } \\
\text { explants (B) }\end{array}$ & $\begin{array}{c}\% \text { Response } \\
\text { (B/A) }\end{array}$ & $\begin{array}{l}\text { No. of } \\
\text { shoot buds } \\
\text { produced }\end{array}$ & $\begin{array}{c}\text { No. of } \\
\text { explants } \\
\text { inoculated (C) }\end{array}$ & $\begin{array}{l}\text { No. of } \\
\text { responding } \\
\text { explants (D) }\end{array}$ & $\begin{array}{l}\text { \% Response } \\
\text { (D/C) }\end{array}$ & $\begin{array}{l}\text { Antibiotic } \\
\text { resistant plants } \\
\text { produced (E) }\end{array}$ & $\begin{array}{c}\text { \% Frequency of } \\
\text { transformation } \\
\text { (E/A) }\end{array}$ \\
\hline 1. & 138 & 50 & 36.23 & 63 & 186 & 83 & 44.62 & 39 & 28.20 \\
\hline 2. & 104 & 49 & 47.11 & 60 & 65 & 39 & 60.00 & 22 & 21.15 \\
\hline 3. & 123 & 59 & 47.96 & 76 & 226 & 76 & 33.62 & 28 & 22.76 \\
\hline \multirow[t]{2}{*}{4.} & 194 & 124 & 63.91 & 103 & 319 & 142 & 44.51 & 54 & 27.83 \\
\hline & $559^{c}$ & $282^{c}$ & $48.80^{d}$ & $302^{c}$ & $796^{c}$ & $340^{c}$ & $45.68^{d}$ & $143^{c}$ & $24.98^{d}$ \\
\hline+ Control $^{a}$ & 40 & 40 & 100 & 114 & 230 & 221 & 96.08 & - & - \\
\hline -Control ${ }^{\mathrm{b}}$ & 52 & 8 & 15.3 & 0 & - & - & - & - & - \\
\hline
\end{tabular}

${ }^{a}$ Control tomato leaf explants incubated on MS medium devoid of kanamycin.

${ }^{\mathrm{b}}$ Control tomato leaf explants incubated on MS medium with kanamycin.

${ }^{\mathrm{C}}$ Total number of explants/plants.

${ }^{\mathrm{d}}$ Average value.

transgene (Figure $1 \mathrm{E}$ ). The $\mathrm{T}_{1}$ seeds of all the $25 \mathrm{~T}_{0}$ transgenic plants were screened for segregation of $n p t I I$ gene in $\mathrm{T}_{1}$ progeny. Results showed typical 3:1 Mendelian ratio for segregation of nptII gene and differential quantitative expression of Cry1Ab toxin with corresponding mortality of $\mathrm{H}$. armigera and S. litura larvae (Additional file 1: Table S1). Eventually, five over expressing $T_{0}$ transgenic plants designated as Ab10, Ab13, Ab21, Ab24 and Ab25 expressing Cry1Ab toxin $>0.07 \%$ TSP along with one transgenic plant $\mathrm{Ab} 2$ showing low expression (0.02\% of TSP) were selected for further investigation and analysis (Additional file 1: Table S1). Quantitative Cry1Ab transcript analysis in these $T_{0}$ transgenic plants was performed by quantitative PCR using $\beta$-actin gene of tomato as the internal control. Interestingly, Ab10, Ab24 and Ab25 transgenic plants showed significantly high-level of $c r y 1 A b$ transcript, which was about eight times higher than the low expressing transgenic plant Ab2 (Additional file 2: Figure S1).

Ten $\mathrm{T}_{1}$ transgenic plants designated as Ab2.6, Ab10.2, Ab10.4, Ab13.1, Ab13.4, Ab21.5, Ab21.7, Ab24.4, Ab24.8 and Ab25.3 of respective Ab2, Ab10, Ab13, Ab21, Ab24 and $A b 25 T_{0}$ parents were selected and subjected to PCR analyses. Results of PCR assays for nptII and cry $1 \mathrm{Ab}$ genes showed the expression of expected amplicons of 678 and 800 bp respectively (Figure 1F, G). RTPCR analysis for cry $1 A b$ gene in these $T_{1}$ plants also showed the expression of expected amplicon of $800 \mathrm{bp}$ and reconfirmed the stable inheritance of the transgene (Figure $1 \mathrm{H}$ ). Five of these $\mathrm{T}_{1}$ transgenic plants \# Ab10.4, Ab13.1, Ab21.7, Ab24.4 and Ab25.3 over-expressing Cry1 Ab toxin along with $\mathrm{Ab2.6} \mathrm{T}_{1}$ transgenic plants were used for Southern blot hybridization and results revealed a single-copy insertion of $c r y 1 \mathrm{Ab}$ gene in transgenic plants ID \# Ab10.4, Ab21.7, Ab24.4 and Ab25.3 and two copies in Ab2.6 and Ab13.1 plants respectively (Figure 1I).

\section{Growth characteristics of transgenic plants}

Constitutive expression of Cry1Ab toxin by $D E C a M V 35 S$ promoter did not influence any apparent abnormalities on plant phenotype and overall growth and development of all the $\mathrm{T}_{0}$ transgenic plants. In order to accomplish our aim of selecting a highly overexpressing transgenic line, we selected a single $T_{1}$ transgenic plant Ab25.3 derived from Ab25 $\mathrm{T}_{0}$ parent on the basis of Bt-Cry1Ab protein content for further investigation. Five over expressing lines of Ab25.3 $\mathrm{T}_{1}$ parent designated as Ab25 A, Ab25 B, Ab25 C, Ab25 D and Ab25 E were identified and selected in $\mathrm{T}_{4}$ generation on the basis of consistent expression of $\mathrm{Cry} 1 \mathrm{Ab}$ toxin and overall growth and yield of transgenic plants. The transgenic plants of Ab25 E line consistently showed maximum expression of Cry1 Ab toxin and normal growth amongst the five overexpressing transgenic lines and selected for detail characterization. Compared to the wild type, only the onset of flowering in the transgenic lines was delayed. The onset of flowering occurred after $30 \pm 1$ days in the wild type plants whereas $34 \pm 2$ days in Ab25 $\mathrm{E}$ line. The average number of fruits and seeds per plant in the wild type were $14 \pm 4$ and $2.57 \pm 0.10$, while in Ab25 E line it was $12 \pm 2$ and $2.49 \pm 0.10$ respectively. The average plant dry weight of Ab25 E transgenic line ( $510 \pm 11.23 \mathrm{~g})$ was near to the wild type $(552 \pm 45.28 \mathrm{~g})$, suggesting no apparent affect on plant growth parameters between the wild type and transgenic plant (Table 3). Some of the high expressing transgenic tomato plants did show reduction in overall growth and fruit yield and were discarded (data not shown).

\section{Quantitative Cry $1 \mathrm{Ab}$ expression and corresponding insect mortality}

The Cry1 $\mathrm{Ab}$ toxin in $\mathrm{T}_{0}$ and $\mathrm{T}_{1}$ transgenic tomato plants was examined by DAS-ELISA and calculated as the percentage of Bt-toxin in total soluble protein (TSP). 
Table 3 Comparative assessment of different growth parameters in selected high expressing transgenic tomato plants of $\mathrm{T}_{4}$ generation

\begin{tabular}{|c|c|c|c|c|c|}
\hline $\begin{array}{c}\text { Transgenic } \\
\text { lines }\end{array}$ & $\begin{array}{l}\text { Cry1 Ab toxin } \\
\text { (\% of TSP) }\end{array}$ & $\begin{array}{l}\text { a Onset of flowering } \\
\text { (days after sowing) }\end{array}$ & $\begin{array}{l}{ }^{\mathrm{b}} \text { Average no. of } \\
\text { fruits / plant }\end{array}$ & $\begin{array}{c}\text { CNo. of seeds / } \\
\text { fruit / g }\end{array}$ & ${ }^{\text {d}}$ Dry wt. (g) \\
\hline Wild type & - & $30 \pm 1$ & $14 \pm 4$ & $2.57 \pm 0.10$ & $552 \pm 45.28$ \\
\hline Ab25 A & $0.37 \pm 0.004$ & $40 \pm 3(0.013)^{*}$ & $11 \pm 1(0.225)$ & $2.48 \pm 0.08(0.016)$ & $475 \pm 11.52(0.059)$ \\
\hline Ab25 B & $0.19 \pm 0.004$ & $36 \pm 2(0.009)$ & $9 \pm 2(0.049)$ & $2.5 \pm 0.10(0.426)$ & $456 \pm 5.78(0.052)$ \\
\hline Ab25 C & $0.14 \pm 0.004$ & $38 \pm 2(0.005)$ & $8 \pm 3(0.009)$ & $2.54 \pm 0.20(0.655)$ & $450 \pm 3.33(0.052)$ \\
\hline Ab25 D & $0.39 \pm 0.002$ & $36 \pm 3(0.035)$ & $11 \pm 2(0.122)$ & $2.45 \pm 0.09(0.002)$ & $482 \pm 6.25(0.090)$ \\
\hline Ab25E & $0.47 \pm 0.003$ & $34 \pm 2(0.020)$ & $12 \pm 2(0.225)$ & $2.49 \pm 0.10(0.300)$ & $510 \pm 11.23(0.166)$ \\
\hline
\end{tabular}

${ }^{a}$ Average number of days for onset of flowering from seed sowing, in 20 transgenic tomato plants of each line.

${ }^{\mathrm{b}}$ Average number of fruits per plant in 20 transgenic tomato plants of each line.

${ }^{c}$ Average number of seeds (per gram of fruit) in eight fruits of individual transgenic plant, in 20 plants of each line.

${ }^{\mathrm{d} D r y}$ weight of 20 transgenic tomato plants of each line.

"Values in parenthesis indicate the probability associated with a student's paired $t$-test.

When $P<0.05$ the difference of the individual parametric value to that of the value of the control was significant.

Cry1Ab toxin content in the third group of 25 independent $\mathrm{T}_{0}$ plants ranged between $0.02-0.13 \%$ of TSP and resistance bestowed against the fruit worm $H$. armigera and cut worm S. litura corresponding to the Cry1 Ab level is shown in Figure 2A. The expression level of Cry1 Ab toxin in $\mathrm{T}_{1}$ population was increased over their $\mathrm{T}_{0}$ parents. The $T_{1}$ transgenic plants of the respective $T_{0}$ parents Ab10, Ab24 and Ab25 showed $0.37 \pm 0.004,0.39 \pm 0.002$ and $0.47 \pm 0.003 \%$ Cry1 Ab toxin of TSP, respectively and resulted $100 \%$ mortality of $H$. armigera after $48 \mathrm{~h}$ feeding on the detached vegetative leaves (Figure $2 \mathrm{~B}$ ).

As expected the cry $1 A b$ gene under DECaMV35S constitutive promoter was expressed in all the parts of $\mathrm{T}_{0}$ transgenic tomato \# Ab25 plant and level of Cry1 Ab toxin was in the order, flower $>$ seed $>$ sepal $>$ raw pulp $>$ raw pericarp $>$ leaf $>$ stem $>$ root $>$ ripe pericarp $>$ ripe pulp (Additional file 3: Figure S2). A similar pattern of Cry 1Ab toxin expression was found in Ab25 E transgenic line in $\mathrm{T}_{6}$ generation (data not shown).

The $\mathrm{T}_{4}$ transgenic plants of $\mathrm{Ab} 25 \mathrm{~A}, \mathrm{Ab} 25 \mathrm{~B}, \mathrm{Ab} 25 \mathrm{C}$, Ab25D, Ab25E lines and control non transgenic plants developed under contained glass house conditions were subjected to extensive insect bioassay with both the insects. The detached leaves and fruits of the transgenic and control plants were fed to second instar larvae of $S$. litura and $H$. armigera, respectively and results obtained are shown Figure 3 and Additional file 4: Table S2. The leaves and fruits of transgenic lines \# Ab25 A, Ab25 D and Ab25 E, challenged with larvae of S. litura and $H$. armigera showed complete protection against both the insects (Figure 3B-3 to 5, Figure 3C-3 to 5). Insect feeding on mature tomato fruits showed about 17.3\% damage caused to the control fruits (Figure 3C-2), whereas, less than $2.0 \%$ damage was noticed in fruits of transgenic line Ab25 E (Figure 3C-5).

The percent leaf damages inflicted by S. litura on leaves of control plants after $48 \mathrm{~h}$ of feeding was $26.14 \pm 3.91$ while that to Ab25 A, Ab25 B, Ab25 C, Ab25 D, Ab25 E was found to be $0.39 \pm 0.19,3.48 \pm 2.89,3.75 \pm 2.46,0.25 \pm$ 0.12 and $0.20 \pm 0.16$ respectively. Whereas, the percent damages incurred to the control fruits by $H$. armigera after $96 \mathrm{~h}$ of feeding was $17.30 \pm 3.11$ while that in Ab25 A, Ab25 B, Ab25 C, Ab25 D, Ab25 E transgenic plants was $2.96 \pm 1.85,3.54 \pm 2.03,4.70 \pm 2.63,2.72 \pm 1.79$ and $1.71 \pm$ 1.18 respectively. The pictorial representation of percent leaf and fruit damages during insect bioassay are summarized in Additional file 5: Figure S3 and Additional file 6: Figure S4.

\section{Inheritance and expression of $c r y 1 A b$ gene in transgenic plants}

Inheritance of $c r y 1 A b$ gene in the $\mathrm{T}_{1}$ population was analyzed by germination and screening of $\mathrm{T}_{1}$ seeds on kanamycin supplemented medium which revealed segregation according to Mendelian ratio 3:1 (resistant: susceptible, $\mathrm{p} \leq 0.05, \mathrm{x}^{2}=3.841$ ) for kanamycin tolerance (Additional file 1: Table S1). Results of semi-quantitative assessment for stable inheritance of the transgene in 10 randomly selected transgenic plants of Ab25.3 line from $\mathrm{T}_{2}$ to $\mathrm{T}_{6}$ generations are shown in Figure 4A. Southern blot analysis performed with $\mathrm{T}_{4}, \mathrm{~T}_{5}$ and $\mathrm{T}_{6}$ progeny of Ab25 E transgenic line, showed a single band of approximately $10 \mathrm{~kb}$ in size, hybridizing with the $c r y 1 A b$ gene probe (Figure 4B). No rearrangement of the $c r y 1 A b$ gene was found in the $T_{6}$ progeny, which indicates that $c r y 1 A b$ transgene was faithfully transmitted into subsequent generations via selfing.

Results of Western blot analysis performed with cell-free protein extracts of $\mathrm{T}_{4}, \mathrm{~T}_{5}$ and $\mathrm{T}_{6}$ progenies of Ab25 E transgenic line showed single band of molecular weight $\sim 65 \mathrm{kDa}$ hybridizing with the polyclonal $\mathrm{Cry} 1 \mathrm{Ab}$ antibodies. The results on expression of toxin protein of $\sim 65 \mathrm{kDa}$, as expected from $1845 \mathrm{bp}$ cry1Ab gene in $\mathrm{T}_{6}$ stage of transgenic plants demonstrates the stable 


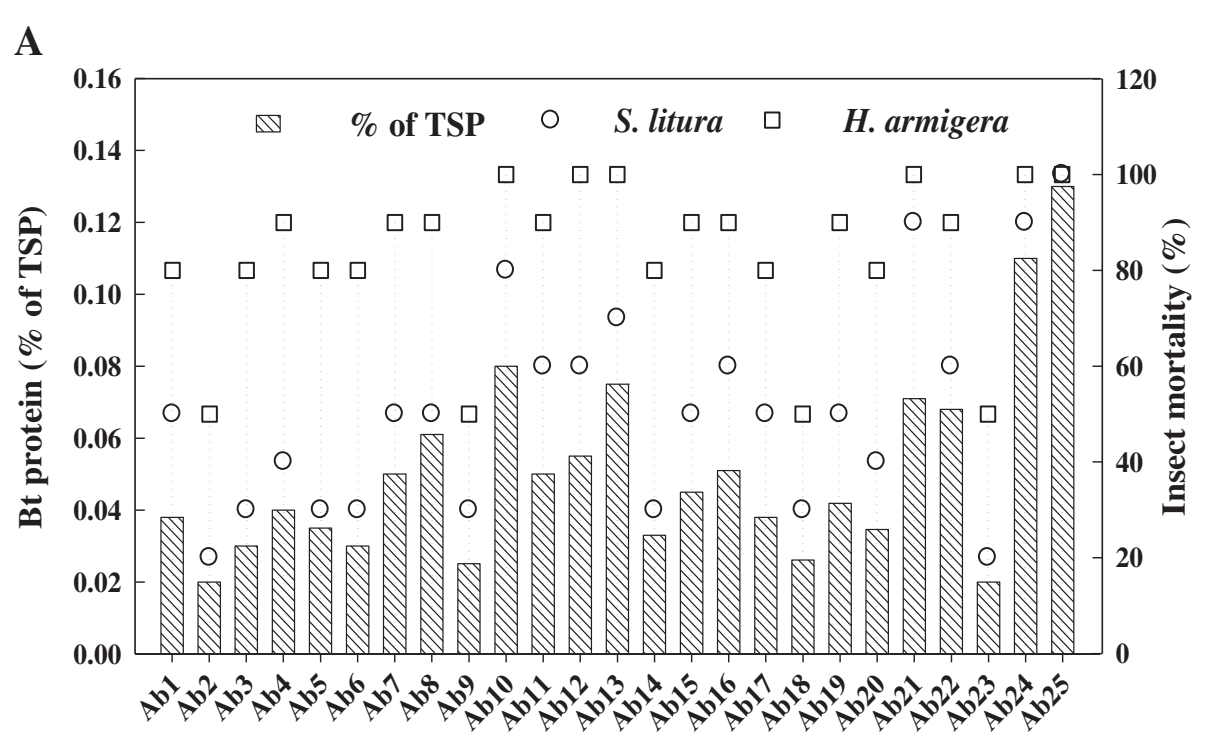

B

Transgenic tomato plants $\left(\mathbf{T}_{\mathbf{0}}\right)$

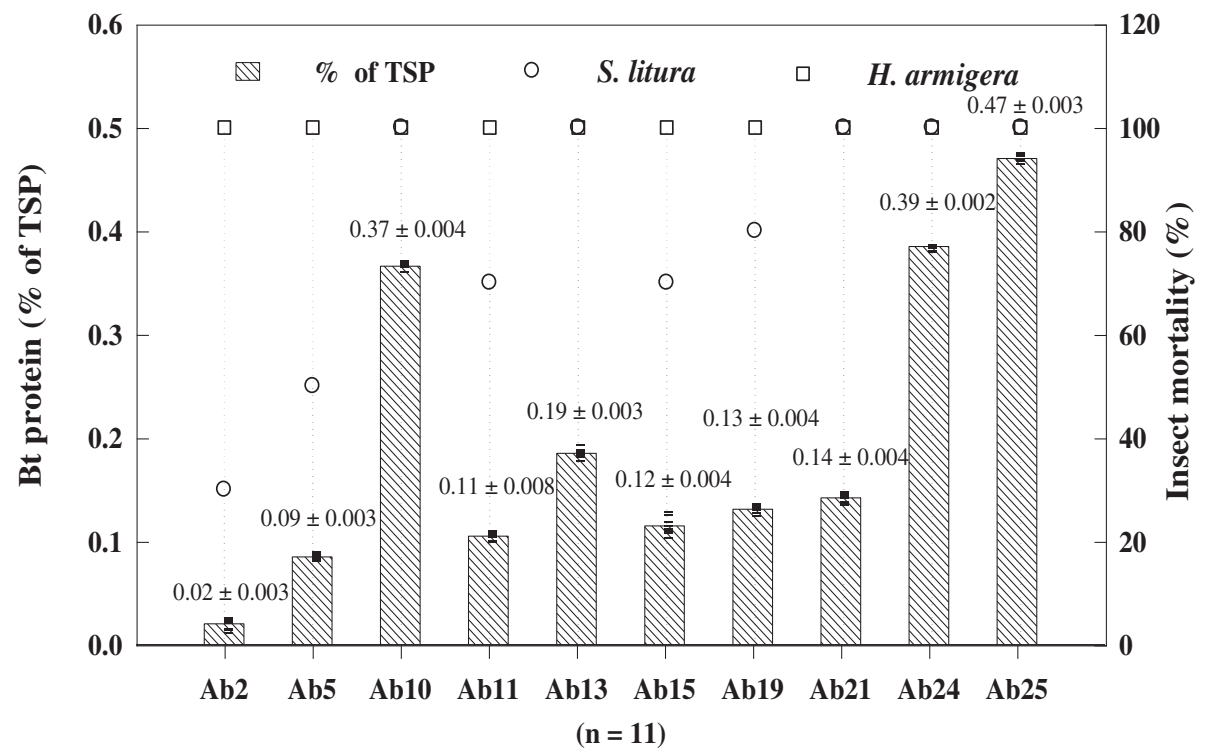

Transgenic tomato plants $\left(\mathrm{T}_{1}\right)$

Figure 2 Quantitative assessment of Bt-Cry1 Ab toxin protein in different $\mathrm{T}_{0}$ plants and selected $\mathrm{T}_{1}$ population. A and $\mathrm{B}$ by double antibody sandwich enzyme-linked immunosorbent assay (DAS-ELISA) as percentage of total soluble protein (TSP) (striped bar) and corresponding insect mortality of $\mathrm{H}$. armigera (open square) and S. litura (open circle). Average quantity of Bt-Cry1Ab toxin in transgenic plants is shown as\%

$\mathrm{TSP} \pm$ standard deviation on the top of histogram bars and also indicated by horizontal mark for individual transgenic plant and ' $n$ ' is the number of $\mathrm{T}_{1}$ transgenic plants.

incorporation of $c r y 1 A b$ gene at a unique locus into transgenic tomato line Ab25 E for stability and consistent over expression of the transgene (Figure 4C).

\section{Receptor binding assay}

The binding efficiency of partially purified BBMV receptor fractions from 5th instar larvae of $H$. armigera and S. litura with partially purified recombinant Cry $1 \mathrm{Ab}$ toxin expressed in transgenic tomato line Ab25 E was checked by DAS-ELISA. The results of the receptor binding assay performed with Cry1Ab toxin $(125 \mathrm{ng} / 100 \mu \mathrm{l})$ showed concentration-dependent response and maximum absorbance of 1.2 and 0.8 with $300 \mathrm{ng} / 100 \mu \mathrm{l} \mathrm{BBMV}$ protein fractions of $H$. armigera and $S$. litura respectively. 


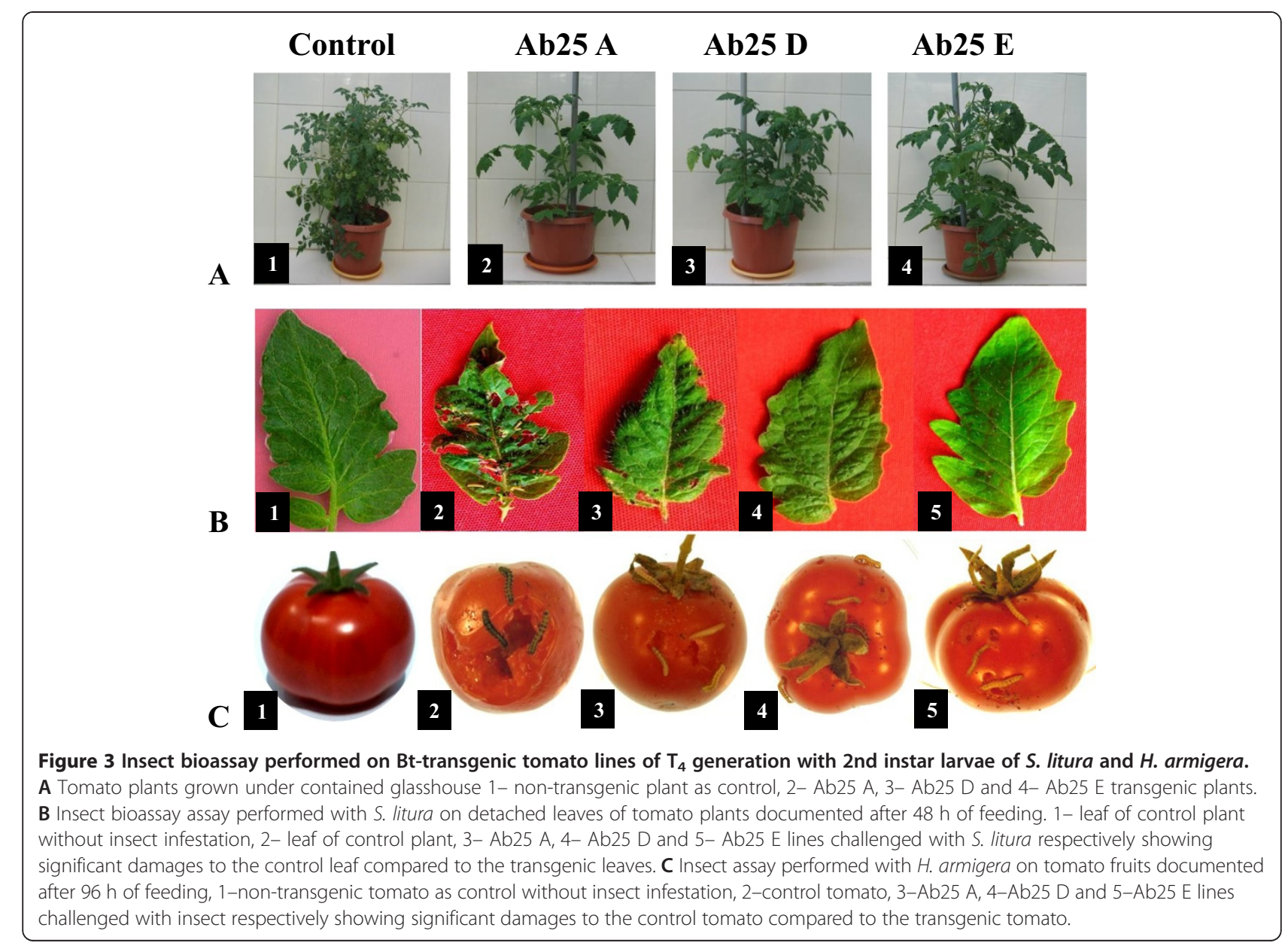

Results summarized in Figure 4D shows microgram $(\mu \mathrm{g})$ quantities of BBMV protein on $\mathrm{x}$-axis in logarithmic scale and corresponding absorbance on $y$-axis. The results of protein-protein interaction was 1.5 fold higher in $H$. armigera than S. litura indicating higher efficacy and abundant binding sites on the brush border epithelium membrane fraction of $H$. armigera compared to S. litura.

\section{Discussion}

Both $H$. armigera and S. litura are serious pests to several important crops world over and particularly in India, affecting a large number of agricultural, forest and horticultural plants. These insects may damage over 45 to $48 \%$ of tomato plants resulting significant loss of tomato yield (up to 35 to $40 \%$ ) in India. The expression of Bt-Cry toxins through transgenic technology in different crop plants for eco-friendly control of insect pests is a revolutionary advancement for enhancement of crop yield (Sanahuja et al. 2011; James 2012). Transgenic cotton and maize expressing recombinant Cry1Ac and Cry $1 \mathrm{Ab}$ toxins were the first genetically transformed crops commercialized for resistance against the highly devastating
Bollworm complex pest, including $H$. armigera and are currently being grown in over 120 million hectares all over the world (Perlak et al. 1990; Fearing et al. 1997; Perlak et al. 2001; Conner et al. 2003; James 2012).

The different Cry1A toxins ( $a, b$, and $c$ ) share close resemblance in having three identical domains, structural homology and mode of action except for their binding efficiency onto the specific receptors and different epitopes of the same receptor such as cadherin-like proteins (CAD), alkaline phosphatase (ALP) and aminopeptidase (APN) (Pigott and Ellar 2007; Fortier et al. 2007). The Cry1Ac toxin is most effective against large number of lepidopteran insects due to efficient oligomerization and binding to these receptors particularly with alkaline phosphatase (Bravo et al. 2004; Upadhyay and Singh 2011). Whereas, Cry $1 \mathrm{Ab}$ toxin is shown to bind rapidly with $\mathrm{BT}-\mathrm{R}_{1}$ receptor involving the stimulation of G-protein adenylyl cyclase/PKA signaling pathway for destabilization of the midgut cytoskeleton, ion channel and pore formation via a different mode of action resulting to mortality of lepidopteran insects (Zhang et al. 2005, 2006; Kato et al. 2006; Padilla et al. 2006). According to recent hypothesis, pore 

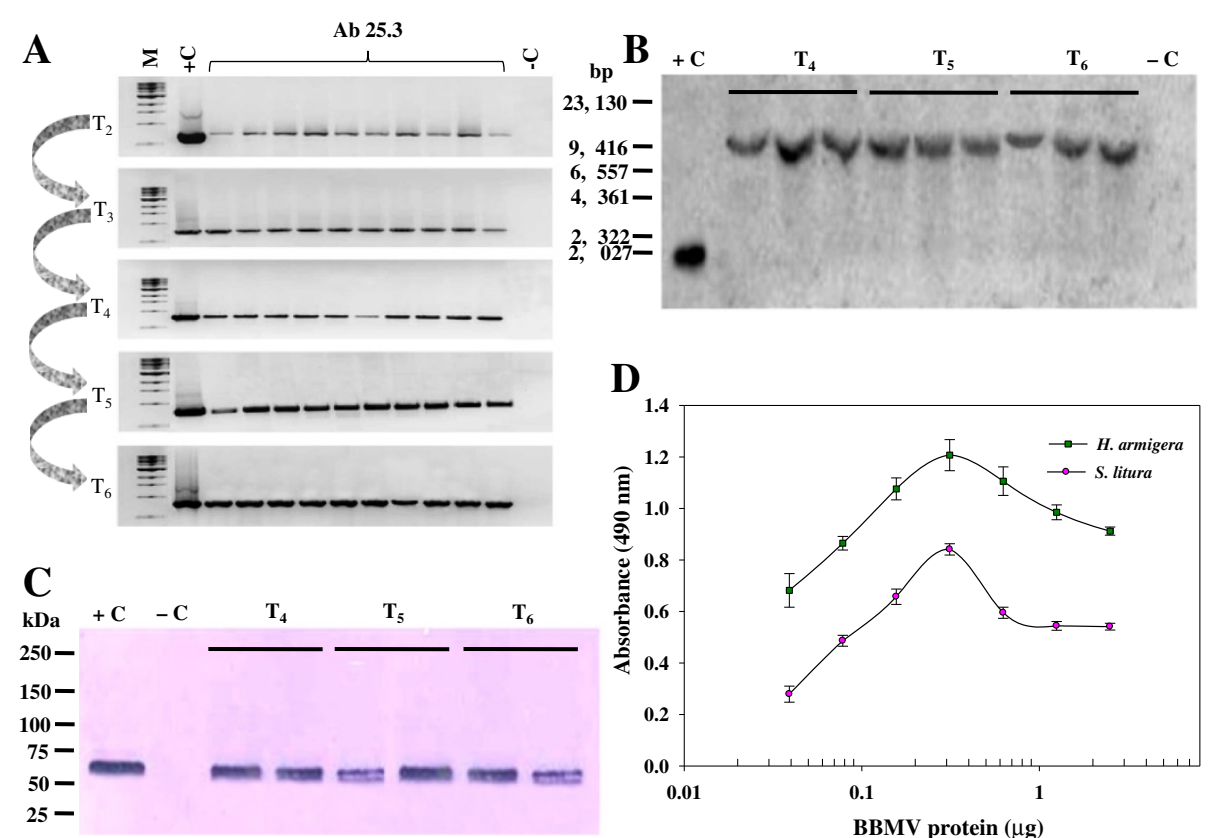

Figure 4 Molecular characterizations of Bt-transgenic progenies and receptor binding assay. A RT-PCR analysis of 10 selected transgenic tomato plants from $T_{2}$ to $T_{6}$ generation of $T_{1}$ transgenic plant Ab25.3. M: $1 \mathrm{~kb}$ ladder, cry 1 Ab amplicon size is 800 bp. B Southern blot hybridization of EcoRl digested DNA from transgenic tomato Ab25 $\mathrm{E}$ line, in $\mathrm{T}_{4}, \mathrm{~T}_{5}$ and $\mathrm{T}_{6}$ generation, $+\mathrm{C} 1845 \mathrm{bp}$ fragment of cry $7 \mathrm{Ab}$ gene as positive control, $-\mathrm{C}$ : Genomic DNA from non-transformed tomato as negative control. C Western blot with protein extract from Ab25 E transgenic tomato line expressing cry $7 \mathrm{Ab}$ gene in $T_{4}, T_{5}$ and $T_{6}$ generations, $+C$ : partially purified Bt-protein of $\sim 65 \mathrm{kDa},-C$ as positive control: Total protein isolated from non-transformed

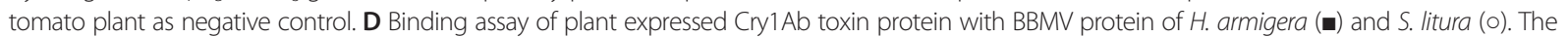
BBMV protein fraction $(300 \mathrm{ng} / 100 \mu \mathrm{l})$ from both the insects were coated and shown in long scale while Cry $1 \mathrm{Ab}$ toxin protein (125 ng/ $100 \mu \mathrm{ll})$ was used for protein-protein interaction followed by immuno absorbance assay.

formation is attributed to interaction of Cry1A toxins first with ALP and APN to concentrate and resulting activated toxin to bind with CAD receptor involving three epitopes CR 7, CR 11 and CR 12 for Cry1Ac and only two epitopes CR11 and CR12 for Cry1Ab, therefore, reflecting differential order of toxicity Cry1Ac $>$ Cry1Ab and minimal for Cry1Aa (Kato et al. 2006; Pardo Lopez et al. 2013).

Earlier studies on engineering of tomato expressing either cry1Ab or cry1Ac gene (Fischhoff et al. 1987; Delannay et al. 1989; Mandaokar et al. 2000; Kumar and Kumar 2004) have shown protection against either tomato fruit worm (Heliothis zea) and tobacco hornworm (Manduca sexta) or tomato fruit borer (Helicoverpa armigera). However, selection of the transgenic tomato line $\mathrm{Ab} 25 \mathrm{E}$ in $\mathrm{T} 4$ generation amongst the segregating population seems to be unique, showing complete protection against two different serious lepidopteran insect-pests without any yield penalty.

Interestingly, in spite of several modifications incorporated in cry $1 A$ genes and successful commercial cultivation of Bt-cotton, Bollgard I and II expressing Cry1Ac toxin and Cry1Ac + Cry2Ab toxins respectively, but obtaining transgenic plants expressing high-level of Cry1Ac is an exceptionally rare and random event (Perlak et al.
2001; Rawat et al. 2011). This is particularly due to some uncharacterized circumstances owing to the expression of Cry1Ac toxin that imparts negative effect and inhibits the in vitro regeneration and development of highly expressing transgenic events (Diehn et al. 1996; De Rocher et al. 1998). Recently, Cry1Ac toxin has been welldocumented to exert detrimental effects on the regeneration of cotton and tobacco transgenics expressing the toxin protein above $>0.002-0.005 \%$ of TSP (Rawat et al. 2011). The selection of Monsanto 531 event of transgenic Coker cotton, expressing high-level of Cry1Ac toxin from full-length, modified, synthetic cry1Ac like gene, is perhaps a chance phenomenon for possible introgression of the $c r y 1 A c$ gene in the hot-spot region of cotton genome, resulting in very high expression of toxin, without any detrimental effect on the growth parameters (Perlak et al. 2001; Purcell et al. 2004; Zhang et al. 2008). Coexpression of two different Bt-cry genes, without affecting the overall growth either by direct gene transformation or introgression through conventional breeding is still not routine, except for few reports in recent years (Cao et al. 2008; Mehrotra et al. 2011).

The transgenic line Ab25 E of tomato upto $\mathrm{T}_{6}$ generation has consistently exhibited high expression of 
Cry1Ab toxin and complete protection against two different lepidopteran insects without affecting the growth and yield parameters. There is no evidence till date, of any in vivo toxicity of Cry $1 \mathrm{Ab}$ on initial regeneration and development of plants transformed with $c r y 1 \mathrm{Ab}$ gene (Kumar and Kumar 2004; Rawat et al. 2011). One instance can be recalled where the transgenic event Bt176 of Bt-cry1Ab maize was found to be detrimental against non-target pest monarch butterfly feeding on pollen of transgenic maize because cry $1 A b$ gene was driven by pollen specific promoter (Sears et al. 2001). The cultivated tomato is strictly self-pollinated crop (cleistogamous nature of flower) and pollen specific promoter is not used for expression $c r y 1 A b$ gene, therefore, the possibility of pollen-toxicity is ruled out in our case. Although, the use of single $c r y 1 A b$ gene targeted against African maize stem borer in Bt-maize did not endure longer, and enforcement of high refugia and gene pyramiding strategy had prevented the development of resistance (Berg et al. 2013; Tabashnik et al. 2011).

Our data with large number of primary $T_{0}$ transformants having single copy of the transgene showed typical Mendelian inheritance for single dominant trait with consistent improvement of Cry1Ab protein expression in subsequent generations, particularly in transgenic line Ab25.3 from $T_{2}$ to $T_{4}$ and results are similar to earlier reports (Fearing et al. 1997; Perlak et al. 2001). The best transgenic line Ab25 E in $\mathrm{T}_{4}$ generation amongst the five promising lines was selected, showing high expression of Cry1Ab toxin with single copy incorporation of modified cry $1 A b$ gene as evident from Southern blot analyses of $\mathrm{T}_{4}, \mathrm{~T}_{5}$ and $\mathrm{T}_{6}$ progenies of the transgenic plant.

Our results for over-expression of Cry1Ab in transgenic line Ab25 E showing effective toxicity against $S$. litura are similar to earlier reports of Bt-maize (Dutton et al. 2005; Berg et al. 2013). The high toxicity and strong efficacy against two different lepidopteran insects seems to reflect the synergistic interaction of high-level of Cry1Ab toxin with all possible available receptors or targets on the brush border membrane in both the insects. The results of receptor binding assay of midgut preparations with partially purified recombinant Bt-Cry1Ab toxin expressed in transgenic tomato plants corroborates well with our observed data for efficient protection against two different pests, as compared to earlier reports of toxicity to $H$. armigera only (Mandaokar et al. 2000; Kumar and Kumar 2004). Our results reflect the possible incorporation of the modified $c r y 1 A b$ gene in the hot-spot locus of euchromatin region of the tomato genome for significant higher expression (Klee and Giovannoni 2011; The Tomato Genome Consortium, 2012), without affecting the growth parameters, similar to MON531 transgenic event of cotton (Perlak et al. 2001).

\section{Conclusions}

To conclude the efficient insecticidal response of transgenic tomato line Ab25 E is due to the synergistic response of the over-expression of modified $c r y 1 A b$ gene and efficient binding of Cry1Ab toxin with the different receptors and other possible target proteins located in the midgut of the two insects. This over expressing homozygous transgenic line can be deployed in tomato breeding programme for the introgression of insectresistant trait in other commercially important varieties of tomato.

\section{Methods}

\section{Agrobacterium strain and gene construct}

Agrobacterium tumefaciens strain LBA4404 harbouring binary vector pBIN200 with modified and truncated 1845 bp cry $1 A b$ gene (Sardana et al. 1996) driven by double enhancer CaMV35S promoter and neomycin phosphotransferase gene (nptII) for kanamycin resistance in pBIN 20 backbone (Hennegan and Danna 1998) has been used for tomato transformation as shown in Figure 1A. Cultures of $A$. tumefaciens were grown at $28^{\circ} \mathrm{C}$ in YEB medium containing $20 \mathrm{mg} \mathrm{l}^{-1}$ rifampicin, $50 \mathrm{mg} \mathrm{l}^{-1}$ kanamycin and $50 \mathrm{mg} \mathrm{l}^{-1}$ streptomycin for $24 \mathrm{~h}$ at $200 \mathrm{rpm}$ and utilized for transformation of tomato leaf-discs.

\section{Plant material and explant preparation}

Breeder seeds of tomato (Solanum lycopersicum L.) variety Pusa early dwarf (PED), obtained from National Seeds Corporation, New Delhi, India, were surface sterilized and germinated on semi-solid MS medium (Murashige and Skoog 1962), containing B5 vitamins (Gamborg et al. 1968), 3\% (w/v) sucrose (HiMedia Labs, Mumbai, India) and $8 \mathrm{~g} \mathrm{l}^{-1}$ agar (Sigma, USA) followed by incubation at $24 \pm 2^{\circ} \mathrm{C}$ in dark and shifted after three days of 16:8 h light-dark cycle in culture room maintained at $22 \pm 2{ }^{\circ} \mathrm{C}$, illuminated with light intensity of $100 \mu \mathrm{mol} \mathrm{m} \mathrm{m}^{-2} \mathrm{~s}^{-1}$ and $78 \pm 4 \%$ relative humidity. Vegetative leaves from axenic tomato seedlings of 16-18 days, were excised and initially pre-cultured on MS medium supplemented with $2.5 \mathrm{mg} \mathrm{l}^{-1}$ 6-benzyladenine (BAP) + $0.5 \mathrm{mg} \mathrm{l}^{-1}$ indole-3-acetic acid (IAA) for three days prior to Agrobacterium co-cultivation (Koul et al. 2012).

\section{Agrobacterium-mediated transformation and plantlet regeneration}

Tomato leaf discs were dipped in Agrobacterium suspension $\mathrm{OD}_{600} \approx 0.25-0.3\left(2 \times 10^{9} \mathrm{cfu} \mathrm{ml}^{-1}\right)$, in MS liquid co-cultivation medium supplemented with $100 \mu \mathrm{M}$ acetosyringone (As) for $20 \mathrm{~min}$. The leaf disc explants were dried on sterilized blotting paper and transferred onto co-cultivation medium comprising of MS salts $+3 \%(\mathrm{w} / \mathrm{v})$ maltose $+100 \mu \mathrm{M} \mathrm{As}+2.5 \mathrm{mg} \mathrm{l}^{-1} \mathrm{BAP}+0.5 \mathrm{mg} \mathrm{l}^{-1} \mathrm{IAA}$ 
and co-cultivated in dark, for two days in the culture room. The explants thereafter were incubated on medium consisting of MS salts $+3 \%(\mathrm{w} / \mathrm{v})$ maltose + $500 \mathrm{mg} \mathrm{l}^{-1}$ cefotaxime $+2.5 \mathrm{mg} \mathrm{l}^{-1} \mathrm{BAP}+0.5 \mathrm{mg} \mathrm{l}^{-1}$ IAA for 5-7 days and then transferred to shoot induction medium one (SIM-1) containing MS salts $+3 \%(\mathrm{w} / \mathrm{v})$ maltose $+2.5 \mathrm{mg} \mathrm{l}^{-1} \mathrm{BAP}+0.5 \mathrm{mg} \mathrm{l}^{-1} \mathrm{IAA}+250 \mathrm{mg} \mathrm{l}^{-1}$ cefotaxime $+50 \mathrm{mg} \mathrm{l}^{-1}$ kanamycin and incubated for 21 days for the first screening of putative transgenic plants ( ${ }^{\text {st }}$ selection). The independent regenerated shoots with a pair of vegetative leaves developed on first cycle of kanamycin screening were identified and their first pair of vegetative leaves were excised, sub-cultured on the shoot induction medium supplemented with kanamycin (SIM-2) for successive second screening and selection of transgenic shoots. The independent shoots that regenerated after successive II $^{\text {nd }}$ selection cycles were subcultured on shoot elongation medium (SEM) containing MS medium $+1.0 \mathrm{mg} \mathrm{l}^{-1}$ gibberellic acid $\left(\mathrm{GA}_{3}\right)+3 \%$ $(\mathrm{w} / \mathrm{v})$ sucrose and $50 \mathrm{mg} \mathrm{l}^{-1}$ kanamycin. The shoots recovered from SEM medium having 2-3 leaves were transferred to root induction medium (RIM) containing half-strength $\mathrm{MS}$ medium $+0.5 \mathrm{mg} \mathrm{l}^{-1}$ indole-3-butyric acid (IBA) + $50 \mathrm{mg} \mathrm{l}^{-1}$ kanamycin $+2 \%(\mathrm{w} / \mathrm{v})$ sucrose and $0.8 \%(\mathrm{w} / \mathrm{v})$ agar for 14 days. The rooted plantlets were transferred to plastic pots containing sterilized soilrite (Keltech Energies Ltd. Bengaluru, India) and irrigated with half-strength liquid MS medium devoid of sucrose. The pots were kept in a plant growth chamber (Conviron Adaptis 1000 PG, Canada) set at desired relative humidity starting from 90 to $70 \%$ for 14 days of hardening. The hardened plantlets were potted in earthen pots filled with soil: sand: farmyard manure (in 3:1:1 ratio) and transferred to glasshouse maintained at $24 \pm 1^{\circ} \mathrm{C}$ under natural light for normal growth, development, flowering and seed setting.

Selfed seeds of the primary $\mathrm{T}_{0}$ transformants and transgenic plants were germinated on solidified halfstrength MS medium supplemented with $50 \mathrm{mgl}^{-1}$ kanamycin for segregation and selection of transgenic progeny.

\section{PCR and Southern blot analysis}

Genomic DNA from leaves of primary $T_{0}$ and transgenic plants was isolated using GenElute plant genomic DNA miniprep kit, according to the manufacturer's instructions (Sigma, USA). PCR amplification of $c r y 1 A b$ and $n p t I I$ genes from plant genomic DNA (100 ng) was achieved by using set of primers amplifying $678 \mathrm{bp}$ and 800 bp amplicon of $n p t \mathrm{II}$ and $c r y 1 A b$ genes respectively, in the GeneAmp ${ }^{\oplus}$ PCR system 9700 (PE Biosystems, USA). The set of primers for nptII gene was forward $5^{\prime}-$ TATTCGGCTATGACTTGGGC-3' and reverse 5 '-GCG AACGCTATGTCCTGATA-3', while for $c r y 1 A b$ gene forward primer was 5'-TGGTACAACACTGGCTTG GA-3' and reverse 5'-ATGGGATTTGGGTGATTT GA-3'. Southern blot hybridization was performed to confirm the integration of T-DNA into the genome of the transgenic plants according to Sambrook et al. (1989). Aliquot of $10 \mu \mathrm{g}$ genomic DNA purified from the transgenic plants $\left(\mathrm{T}_{0}-\mathrm{T}_{6}\right.$ generation) was digested overnight with EcoRI, cutting at single site within the T-DNA followed by gel electrophoresis and transferring onto BioBond Plus nylon membrane (Sigma, USA). The blot was hybridized at $58^{\circ} \mathrm{C}$ for $24 \mathrm{~h}$ with $1845 \mathrm{bp}$ fragment of $c r y 1 A b$ gene radio labeled with $\alpha \mathrm{P}^{32} \mathrm{dCTP}$ (BRIT, Mumbai India) and washed under stringent conditions, exposed to Fuji screen for $48 \mathrm{~h}$ followed by scanning and documentation on Typhoon Trio Plus phosphoimager (GE Healthcare Life Sciences AB, Sweden).

\section{RT-PCR and quantitative real-time quantitative PCR (qPCR)}

RT-PCR analysis of transgenic plants was done by synthesis of first-strand of cDNA with enhanced Avian RT-PCR kit using $5 \mu \mathrm{g}$ of total RNA purified from the transgenic plant according to manufacturer's instructions (Sigma, USA). The relative quantity of $c r y 1 A b$ transcripts in transgenic tomato plants was analyzed by quantitative PCR performed in StepOne real-time PCR system (Applied Biosystems, USA) using Quantifast SYBR green PCR kit (Qiagen, Germany). Tomato $\beta$-actin gene (GenBank accession no. U60482) was used as endogenous control in all real-time PCR assays. The nucleotide sequences of the set of forward and reverse primers for $c r y 1 A b$ gene were 5'-AAGGATTCTCCCACAGGTTG-3' and 5'-ATGGGA TTTGGGTGATTTGAG-3' respectively, while for $\beta$-actin gene the forward 5 -GCTGGATTTGCTGGAGATGAT GA-3' and reverse 5'-TCCATGTCATCCCAATTGCTA AC-3' giving an amplicon of 157 and 194 bp respectively. Total RNA extracted from $100 \mathrm{mg}$ of leaf tissues was reverse transcribed into cDNA and used as template in realtime PCR assays with $c r y 1 A b$ and $\beta$-actin gene-specific primers. Reverse transcription reaction was performed at $50^{\circ} \mathrm{C}$ for $10 \mathrm{~min}$ with initial denaturation at $95^{\circ} \mathrm{C}$ for 5 min (for activation of Hot-start Taq polymerase) followed by 40 amplification cycles comprising of $10 \mathrm{~s}$ denaturation at $95^{\circ} \mathrm{C}$ and combined annealing and extension for $30 \mathrm{~s}$ at $60^{\circ} \mathrm{C}$ in $25 \mu$ reaction mixture, according to manufacturer's instructions (Qiagen, Germany). The relative values obtained from the quantitation of mRNA were expressed as $2^{-\Delta \Delta \mathrm{Ct}}$ where $\Delta \mathrm{Ct}$ represents the difference between $\mathrm{Ct}$ (cycle threshold) values of a target and the endogenous control $(\beta$-actin $)$ in the same sample and $\Delta \Delta C t$ is the difference between the $\Delta \mathrm{Ct}$ value of a particular sample and that of the reference sample. The quantitative data of realtime PCR represent mean values with standard error of three independent experiments with three replicates of the transgenic plant. 


\section{Quantitative estimation of recombinant Cry1Ab toxin}

Vegetative leaves or other plant parts from 12 weeks old transgenic tomato plants of $\mathrm{T}_{0}-\mathrm{T}_{6}$ generations were used for protein extraction by grinding in 1:10 (w/v) ratio of plant tissue to PBST buffer ( $\mathrm{pH} 7.4)$, in liquid nitrogen. The total soluble protein (TSP) concentration in cell-free extracts was determined by Bradford dyebinding procedure with bovine serum albumin (BSA) as standard protein (Bio-Rad, USA). The quantitative estimation of expressed recombinant Cry1Ab toxin in cellfree extracts of transgenic plants was determined by DAS-ELISA, using peroxidase labeled PathoScreen kit for Bt-Cry1Ab/1Ac protein (Agdia, USA). Cell-free extracts from leaves of transgenic plants were dispensed into wells of ELISA plate, pre-coated with primary antibody followed by reaction with secondary antibody conjugated with alkaline phosphatase to develop colour and detection of Cry1 Ab toxin was monitored at $650 \mathrm{~nm}$ using SpectraMax 340PC spectrophotometer (Molecular Devices, USA). Expression levels were quantified on a linear standard curve plotted with pure Bt-Cry1Ab protein (Agdia, USA).

\section{Western immunoassay}

Western immunoassay was performed with cell-free extracts of transgenic tomato plants expressing Cry1 $\mathrm{Ab}$ toxin as described earlier (Sambrook et al. 1989). Aliquots of the total plant protein samples were boiled for $10 \mathrm{~min}$ with $2 \times$ sample loading dye $[50 \mathrm{mM}$ Tris $-\mathrm{HCl}$ (pH 6.8), 100 mM DTT, 2\% SDS, 0.1\% bromophenol blue and $10 \%$ glycerol] and electrophoresed on $10 \%$ denaturing SDS-PAGE. The resolved protein bands on SDS-PAGE were transferred onto immunoblot ${ }^{\mathrm{m}}$ PVDF membrane (Bio-Rad, USA) using SD semi-dry transfer cell (Bio-Rad, USA) in transfer buffer (25 mM Tris base, $192 \mathrm{mM}$ glycine $(\mathrm{pH}$ 8.3) and $0.1 \%$ SDS]. The membranes were blocked for $2 \mathrm{~h}$ at $25^{\circ} \mathrm{C}$ in blocking buffer and incubated with primary antibody (rabbit polyclonal to $B$. thuringiensis Cry1 Ab toxin protein, Agdia, USA) diluted to 1:1000 ratio in blocking buffer, for $2 \mathrm{~h}$ at $25^{\circ} \mathrm{C}$. The membranes were washed four times with PBST, followed by incubation with secondary antibody (goat polyclonal to rabbit IgGalkaline phosphatase conjugated antibody, Sigma, USA) at 1:5000 dilution for $2 \mathrm{~h}$ at $25^{\circ} \mathrm{C}$ and colour development with BCIP-NBT substrate solution (Sigma, USA).

\section{Insect bioassay}

The larval population of $H$. armigera and S. litura were reared in the insectary on an artificial diet (Gupta et al. 2004) at $26 \pm 2^{\circ} \mathrm{C}, 70 \%$ relative humidity and $14 \mathrm{~h}$ light/ $10 \mathrm{~h}$ dark regime. The detached leaves from fourth to sixth nodes of untransformed control and transgenic plants of $T_{0}$ to $T_{6}$ generations were washed thoroughly with distilled water, blotted dry and placed in a plastic container with 10 number of second instar larvae of $H$. armigera or S. litura per leaf, in two replicates. Feeding was allowed for $48-96 \mathrm{~h}$ and the data on larval weight and percent mortality were analyzed statistically and results were co-related to the quantitative expression of Cry1 Ab toxin. The green leaves and mature fruits of selected transgenic lines in $T_{4}$ generation grown in glasshouse were also used for insect bioassay with second instar larvae of $H$. armigera and S.litura, respectively. Percent damage to untransformed control and transgenic leaf or fruit was considered as a function of loss in leaf area and fruit weight due to insect feeding. The leaf lamina was traced on the Whatman $3 \mathrm{MM}$ paper, cut and weighed. The damaged portion of the leaf after insect bioassay was traced on the previously cut paper leaf and carefully removed and the damaged paper leaf was again weighed. Leaf area was calculated by dividing the weight of paper leaf by the weight of one $\mathrm{cm}^{-2}$ Whatman $3 \mathrm{MM}$ paper. The leaf area after insect feeding was calculated similarly and finally the percent loss in leaf area was calculated by the formula (initial area - area after insect feeding) / initial area $\times 100$. Similarly, the percent damage to fruits was calculated by the formula (initial weight - weight after insect feeding) / initial weight $\times 100$. The leaf bioassay was performed thrice with five replicates, while the fruit bioassay was performed once with five replicates and the results were statistically analyzed by Student's $t$-test.

\section{Separation of brush border membrane vesicles (BBMV) from the midgut of $H$. armigera and S. litura}

BBMV were prepared by the differential magnesiumprecipitation method of Upadhyay and Singh (2011). Fifth instar larvae were anaesthetized by placing them on ice for $5 \mathrm{~min}$ and dissected in MET buffer [300 mM Mannitol; 5 mM EGTA; 17 mM Tris. $\mathrm{HCl},(\mathrm{pH} 7.4)]$. Midguts were excised from the insects, ground under liquid nitrogen and homogenized in 1:9 (w/v) MET buffer. Equal volume of $24 \mathrm{mM} \mathrm{MgCl} 2$ was added, mixed, kept on ice for $30 \mathrm{~min}$, followed by centrifugation $\left(2500 \times \mathrm{g}, 4^{\circ} \mathrm{C}\right.$, $15 \mathrm{~min})$. The pellet was discarded and the supernatant was centrifuged $\left(30,000 \times \mathrm{g}, 4^{\circ} \mathrm{C}, 30 \mathrm{~min}\right)$. The pellet was resuspended in half of the original volume of MET buffer and $\mathrm{MgCl}_{2}$ and the above steps were repeated. The final pellet was solubilized in phosphate buffered saline (PBS) containing $0.1 \%$ Tween-20, by overnight incubation at $4{ }^{\circ} \mathrm{C}$ with gentle shaking. Protein content of BBMV suspension was measured by Bradford dye-binding assay. The BBMV preparations were used for in vitro interaction studies with partially purified recombinant $\mathrm{Cry} 1 \mathrm{Ab}$ toxin isolated from the leaves of transgenic tomato plants.

\section{Receptor binding assay}

Direct antigen coating enzyme-linked immunosorbent assay (DAC-ELISA) was performed for investigating the 
binding of recombinant $\mathrm{Cry} 1 \mathrm{Ab}$ toxin with partially purified BBMV proteins isolated from fifth instar larvae of $H$. armigera and S. litura. The BBMV suspensions were serially diluted between $2.500 \mu \mathrm{g}-0.040 \mu \mathrm{g}$ per $100 \mu \mathrm{l}$ bicarbonate buffer ( $\mathrm{pH}$ 9.6), coated onto the 96-well ELISA plates and incubated overnight at $4^{\circ} \mathrm{C}$ (Greiner Bio-One, Germany). The ELISA plates were washed with PBST, blocked with 1\% BSA in PBS containing $0.05 \%(\mathrm{w} / \mathrm{v})$ Tween 20 , washed and incubated with known concentration of cell-free leaf extracts of transgenic line $\mathrm{Ab} 25 \mathrm{E}$ and incubated at $37^{\circ} \mathrm{C}$ for $2 \mathrm{~h}$ followed by washing with PBST. The plates were first incubated with Cry1Ab primary antibody (Agdia, USA) for $2 \mathrm{~h}$, followed by washing and incubation for $2 \mathrm{~h}$ with peroxidase-conjugated secondary antibody (Sigma, USA). After washing the ELISA plate with PBST, colour was developed by the addition of $200 \mu \mathrm{l}$ of freshly prepared horseradish peroxidase (HRP) substrate solution (Merck, India) per well and absorbance was monitored at $490 \mathrm{~nm}$. The experiment was repeated three times with three replicates.

\section{Statistical analysis}

Each experiment was performed with five replicates, unless otherwise mentioned and repeated at least three times. Tissue culture data was subjected to analysis of variance by One-Way ANOVA (Gomez and Gomez 1984) to detect the significance of differences among treatment means using Duncan's Multiple Range Test at $P<0.05 . \mathrm{T}_{1}$ seeds were germinated on MS basal medium supplemented with $50 \mathrm{mg} \mathrm{l}^{-1}$ kanamycin and subjected to $X^{2}$ fitness test for progeny segregation to compare the expected and observed data. All graphs were prepared using Sigma Plot software (Sigma Plot, USA).

\section{Additional files}

Additional file 1: Table S1. Segregation analysis of $T_{1}$ transgenic tomato seeds developed with vector pBIN200 and the corresponding insect mortality data of $T_{0}$ transformants.

Additional file 2: Figure S1. Comparative real-time PCR analysis of $c r y 7 A b$ transcript in T0 plants showing fold change in expression with respect to the low expressing transgenic plant Ab2. Control: non-transformed plant.

Additional file 3: Figure S2. Average Bt-Cry1 Ab protein (striped bar) in different parts of T0 transgenic tomato plant Ab25.

Additional file 4: Table S2. Detached leaf and fruit bioassay with $T_{4}$ transgenic plants expressing Bt-CrylAb toxin.

Additional file 5: Figure S3. Control and T4 progeny of transgenic lines Ab25 C, Ab25 B, Ab25 A, Ab25 D and Ab25 E subjected to feeding assay by $S$. litura. Leaf area damage was calculated by the cut paper method.

Additional file 6: Figure S4. Control and T4 progeny of transgenic lines of Ab25 C, Ab25 B, Ab25 A, Ab25 D and Ab25 E subjected to feeding assay by $\mathrm{H}$. armigera. Fruit damage was calculated by fruit weight method.

\section{Abbreviations}

BAP: 6-Benzyladenine; BBMV: Brush border membrane vesicles; Cry: Crystal protein; DECaMV35S: CaMV35S promoter with duplicated enhancer;
IAA: Indole-3-acetic acid; IBA: Indole-3-butyric acid; MS: Murashige and Skoog basal medium; nptll: Neomycin phosphotransferase; PBST: Phosphate buffered saline with Tween-20; TSP: Total soluble protein.

\section{Competing interests}

The authors declare that they have no competing interests.

\section{Authors' contributions}

DVA and IS conceived the project. SS performed tomato transformation and raised the transgenic plants. BK carried out molecular analysis and insect bioassays of the transgenic tomato plants and analysis of the results. BK, DVA and IS wrote the manuscript. BNT and VS critically read and improved the manuscript. All authors read and approved the final manuscript.

\section{Acknowledgements}

We thank Dr. C. S. Nautiyal, Director, CSIR-National Botanical Research Institute, Lucknow, India for valuable suggestions, infrastructural support and CSIR, New Delhi, for providing financial grants for research work under the network project, NWP-03. Thanks are due to Prof. I. Altosaar, Department of Biochemistry, University of Ottawa, Canada for providing modified synthetic truncated Bt-cry 7 Ab gene. We also thank Dr. S. Chandrasekhar for his valuable support and Mr. S.M.H. Abidi for conducting the insect mortality bioassays with transgenic tomato plants.

\section{Author details}

${ }^{1}$ Plant Transgenic Lab, CSIR-National Botanical Research Institute, P.O. Box 436, Rana Pratap Marg, Lucknow 226 001, India. ${ }^{2}$ Department of Microbiology, King George's Medical University (KGMU), Lucknow 226003 , India. ${ }^{3}$ Department of Botany, Guru Ghasidas Vishwavidyalaya, Bilaspur 495 009, Chhattisgarh, India. ${ }^{4}$ Department of Biosciences \& Biotechnology, Banasthali Vidyapith, P.O. Banasthali, Tonk Road, Rajasthan 304 022, India.

Received: 8 November 2013 Accepted: 5 February 2014

Published: 12 February 2014

\section{References}

Arvinth S, Arun S, Selvakesavan RK, Srikanth J, Mukunthan N, Kumar PA, Premachandran MN, Subramonian N (2010) Genetic transformation and pyramiding of aprotinin-expressing sugarcane with $c r y 1 A b$ for shoot borer (Chilo infuscatellus) resistance. Plant Cell Rep 29:383-395

Berg JV, Hilbeck A, Bøhn T (2013) Pest resistance to Cry1 Ab Bt maize: Field resistance, contributing factors and lessons from South Africa. Crop Prot 54:154-160

Bravo A, Gómez I, Conde J, Muñoz-Garay C, Sánchez J, Miranda R, Zhuang M, Gill SS, Soberón M (2004) Oligomerization triggers binding of a Bacillus thuringiensis Cry1 Ab pore-forming toxin to aminopeptidase $\mathrm{N}$ receptor leading to insertion into membrane microdomains. Biochem Biophys Acta 1667:38-46

Bravo A, Likitvivatanavong S, Gill SS, Soberon M (2011) Bacillus thuringiensis: A story of a successful bioinsecticide. Insect Biochem Mol Biol 4:423-431

Cao J, Shelton AM, Earle ED (2008) Sequential transformation to pyramid two Bt genes in vegetable Indian mustard (Brassica juncea L.) and its potential for control of diamondback moth larvae. Plant Cell Rep 27:479-487

Conner AJ, Glare TR, Nap JP (2003) The release of genetically modified crops into the environment Part II. Overview of ecological risk assessment. Plant J 33:19-46

De Rocher EJ, Vargo-Gogola TC, Diehn SH, Green PJ (1998) Direct evidence for rapid degradation of Bacillus thuringiensis toxin mRNA as a cause of poor expression in plants. Plant Physiol 117:1445-1461

Delannay X, La Vallee BJ, Proksch RK, Fuchs RL, Sims SR, Greenplate JT, Marrone PG, Dodson RB, Augustine JJ, Layton JG, Fischhoff DA (1989) Field performance of transgenic tomato plants expressing the Bacillus thuringiensis var. kurstaki insect control protein. Nature Biotechnol 7:1265-1269

Diehn SH, De Rocher EJ, Green PJ (1996) Problems That Can Limit the Expression of Foreign Genes in Plants: Lessons To Be Learned From b.t.-Toxin Genes. In: Setlow JK (ed) Genetic Engineering: Principles and Methods, vol 18. Plenum Press, New York, pp 83-99

Dutton A, Romeis J, Bigler F (2005) Effects of Bt maize expressing cry $7 \mathrm{Ab}$ and Bt spray on Spodoptera littoralis. Entomol Exp Appl 114:161-169

Estela A, Escriche B, Ferre' J (2004) Interaction of Bacillus thuringiensis toxins with larval midgut binding sites of Helicoverpa armigera (Lepidoptera: Noctuidae). Appl Environ Microbiol 70:1378-1384 
Fearing PL, Brown D, Vlachos D, Meghji M, Privalle L (1997) Quantitative analysis of Cry1A(b) expression in Bt maize plants, tissues and silage and stability of expression over successive generations. Mol. Breeding 31:69-176

Fischhoff DA, Bowdish KS, Perlak FJ, Marrone PG, McCormick SM, Niedermeyer JG, Dean DA, Kusano-Kretzmer K, Mayer EJ, Rochester DE, Rogers SG, Fraley RT (1987) Insect tolerant transgenic tomato plants. Nature Biotechnol 5:807-813

Fortier M, Vachon V, Marceau L, Schwatz JL, Laprade R (2007) Kinetics of pore formation by the Bacillus thuringiensis toxin Cry1Ac. Biochem Biophys Acta 1768:1291-1298

Gamborg OL, Miller RA, Ojima K (1968) Nutrient requirements of suspension culture of soybean root cells. Exp Cell Res 50:151-158

Gomez KA, Gomez AA (1984) Statistical Procedures for Agricultural Research. Intl. Rice Res. Inst, 2nd edition. John Wiley and Sons, New York

Gupta GP, Birah A, Ravi S (2004) Development of artificial diet for mass rearing of American bollworm (Helicoverpa armigera). Ind J Agri Sci 74:548-557

Hennegan KP, Danna KJ (1998) pBIN20: An improved binary vector for Agrobacterium-mediated transformation. Plant Mol Biol Rep 16(2):129-131

James C (2012) Global Status of Commercialized Biotech/GM Crops: ISAAA Brief No. 44. ISAAA, Ithaca, NY

Kato T, Higuchi M, Endo R, Maruyama T, Haginoya K, Shitomi Y, Hayakawa T, Mitsui T, Sato R, Hori H (2006) Bacillus thuringiensis Cry1Ab, but not Cry1Aa or Cry1Ac, disrupts liposomes. Pesticide Biochem Physiol 84:1-9

Khan GA, Baksh A, Ghazanfar M, Riazuddin S, Husnain T (2013) Development of transgenic cotton lines harbouring a pesticidal gene (cry $1 A b)$. Emir J Food Agric 25(6):434-442

Klee HJ, Giovannoni JJ (2011) Genetics and control of tomato fruit ripening and quality attributes. Ann Rev Genet 45:41-59

Koul B, Yadav R, Sanyal I, Sawant S, Sharma V, Amla DV (2012) Cis-acting motifs in artificially synthesized expression cassette leads to enhanced transgene expression in tomato (Solanum lycopersicum L.). Plant Physiol Biochem 61:131-141

Kumar H, Kumar V (2004) Tomato expressing Cry1A(b) insecticidal protein from Bacillus thuringiensis protected against tomato fruit borer, Helicoverpa armigera (Hübner) (Lepidoptera: Noctuidae) damage in the laboratory, greenhouse and field. Crop Prot 23:135-139

Mandaokar AD, Goyal RK, Shukla A, Bisaria S, Bhalla R, Reddy VS, Chaurasia A, Sharma RP, Altosaar I, Ananda Kumar P (2000) Transgenic tomato plants resistant to fruit borer (Helicoverpa armigera Hübner). Crop Prot 19:307-312

Mehrotra M, Singh AK, Sanyal I, Altosaar I, Amla DV (2011) Pyramiding of modified $c r y 1 A b$ and $c r y 1 A c$ genes of Bacillus thuringiensis in transgenic chickpea (Cicer arietinum L.) for improved resistance to pod borer insect Helicoverpa armigera. Euphytica 182:87-102

Murashige T, Skoog F (1962) A revised medium for rapid growth and bioassays with tobacco tissue cultures. Physiol Plant 15:473-497

Pacheco S, Gómez I, Arenas I, Saab-Rincon G, Rodríguez-Almazán C, Gill SS, Bravo A, Soberón M (2009) Domain II loop 3 of Bacillus thuringiensis Cry1 Ab toxin is involved in a "ping pong" binding mechanism with Manduca sexta aminopeptidase-N and cadherin receptors. J Biol Chem 284:32750-32757

Padilla C, Pardo-López L, de la Riva G, Gómez I, Sánchez J, Hernandez G, Nuñez ME, Carey MP, Dean DH, Alzate O, Soberón M, Bravo A (2006) Role of tryptophan residues in toxicity of Cry1Ab toxin from Bacillus thuringiensis. Appl Environ Microbiol 72:901-907

Pardo Lopez L, Soberon M, Bravo A (2013) Bacillus thuringiensis insecticidal three-domain Cry toxins: mode of action, insect resistance and consequences for crop protection. FEMS Microb Rev 37:3-22

Perlak FJ, Deaton RW, Armstrong TA, Fuchs RL, Sims SR, Greenplate JT, Fischhoff DA (1990) Insect-resistant cotton plants. Bio/Technology 8:939-943

Perlak FJ, Oppenhuizen M, Gustafson K, Voth R, Sivasupramaniam S, Herring D, Carey B, Ihring RA, Roberts JK (2001) Development and commercial use of Bollgard ${ }^{\circledR}$ cotton in the USA-early promises versus today's reality. Plant J 27:489-501

Pigott CR, Ellar DJ (2007) Role of receptors in Bacillus thuringiensis crystal toxin activity. Microbiol Mol Biol Rev 71:255-281

Purcell JP, Oppenhuizen M, Wofford T, Reed AJ, Perlak FJ (2004) The Story of Bollgard Cotton. In: Christou P, Klee H (ed) Handbook of Plant Biotechnology. John Wiley \& Sons, pp 1147-1163. ISBN: 978-0-471-85199-8

Rawat P, Singh AK, Ray K, Chaudhary B, Kumar S, Gautam T, Kanoria S, Kaur G, Kumar P, Pental D, Burma PK (2011) Detrimental effect of expression of Bt endotoxin Cry1Ac on in vitro regeneration, in vivo growth and development of tobacco and cotton transgenics. J Biosci 36:363-376
Sambrook J, Fritsch EF, Maniatis T (1989) Molecular Cloning: A laboratory Manual, Cold Spring Harbor Laboratory Press. Cold Spring Harbor, NY

Sanahuja G, Banakar R, Twyman RM, Capell T, Christou P (2011) Bacillus thuringiensis: a century of research, development and commercial applications. Plant Biotechnol J 9:283-300

Sardana R, Dukiandjiev S, Giband M, Cheng X, Cowan K, Sauder C, Altosaar I (1996) Construction and rapid testing of synthetic and modified toxin gene sequences cry1A ( $b$ \& $c$ ) by expression in maize endosperm culture. Plant Cell Rep 15:677-681

Schnepf E, Crickmore N, Van Rie J, Lereclus D, Baum J, Feitelson J, Zeigler DR, Dean DH (1998) Bacillus thuringiensis and its pesticidal crystal proteins. Microbiol Mol Biol Rev 62:775-806

Sears MK, Hellmich RL, Stanley-Horn DE, Oberhauser KS, Pleasants JM, Mattila HR, Siegfriedi BD, Dively GP (2001) Impact of Bt corn pollen on monarch butterfly populations: A risk assessment. Proc Natl Acad Sci USA 98:11937-11942

Tabashnik BE, Huang F, Ghimire MN, Leonard BR, Siegfried BD, Rangasamy M, Yang Y, Wu Y, Gahan LJ, Heckel DG, Bravo A, Soberón M (2011) Efficacy of genetically modified Bt toxins against insects with different genetic mechanisms of resistance. Nature Biotechnol 29:1128-1131

The Tomato Genome Consortium (2012) The tomato genome sequence provides insights into fleshy fruit evolution. Nature 485:635-641

Upadhyay SK, Singh PK (2011) Role of alkaline phosphatase in insecticidal action of cry IAc against Helicoverpa armigera larvae. Biotech Lett 33:2027-2036

Vachon V, Laprade R, Schwartz JL (2012) Current models of the mode of action of Bacillus thuringiensis insecticidal crystal proteins: A critical review. J Invertebrate Pathol 111:1-12

Ye GY, Shu QY, Yao HW, Cui HR, Cheng XY, Hu C, Xia YW, Gao MW, Altosaar I (2001) Field evaluation of resistance of transgenic rice containing a synthetic crylAb gene from Bacillus thuringiensis Berliner to stem borers. J Econ Entomol 94(1):271-276

Zhang X, Candas M, Griko NB, Rose-Young L, Bulla LA, Jr (2005) Cytotoxicity of Bacillus thuringiensis Cry1Ab toxin depends on specific binding of the toxin to the cadherin receptor BT-R1 expressed in insect cells. Cell Death Differ 12:1407-1416

Zhang X, Candas M, Griko NB, Taussig R, Bulla LA, Jr (2006) A mechanism of cell death involving an adenylyl cyclase/PKA signaling pathway is induced by the Cry1Ab toxin of Bacillus thuringiensis. Proc Natl Acad Sci USA 103:9897-9902

Zhang J, Cai L, Cheng J, Mao M, Fan X, Meng Z, Chan KM, Zhang H, Oi J, Ji L, Hong Y (2008) Transgene integration and organization in cotton (Gossypium hirsutum L.) genome. Transgenic Res 17:293-306

doi:10.1186/2193-1801-3-84

Cite this article as: Koul et al:: Transgenic tomato line expressing modified Bacillus thuringiensis cry $1 \mathrm{Ab}$ gene showing complete resistance to two lepidopteran pests. SpringerPlus 2014 3:84.

\section{Submit your manuscript to a SpringerOpen ${ }^{\circ}$ journal and benefit from:}

- Convenient online submission

- Rigorous peer review

- Immediate publication on acceptance

- Open access: articles freely available online

- High visibility within the field

- Retaining the copyright to your article

Submit your next manuscript at springeropen.com 